\title{
ANALISIS PRINSIP EKONOMI ISLAM TERHADAP OPERASIONAL PRODUK INVESTASI EMAS PADA PERBANKAN SYARIAH $\mathrm{X}$
}

\author{
Oleh: Anggoro Sugeng ${ }^{1}$
}

\begin{abstract}
Investment is one of the important instruments as collateral in the future for every human being. Especially for those who wish to gain happiness through investment patterns. Islamic financial institutions are now growing rapidly can be an alternative for customers who wish to invest. The purpose of this study was to determine oprasional Gold Investment in Islamic banking-related goals, mechanisms, customer requirements the applicant, term, collateral, benefits and fees charged to customers in terms of the applicant's gold investment principles of Islamic economy in the form of fatwas and outlook muamalah fiqh. This study uses field research by visiting the direct object of study to obtain the required files through interviews, observation on operationality of Gold Investment. While the analysis is used to process the data that has been obtained is descriptive analysis to produce results. Results from this study is that Gold Investment to buy mortgage scheme on Islamic banking has not fully correspond to some Fiqh Fatwa and views, that the clarity of the goods at the contract, which contains the value of speculative investments and lack of compliance with the Standard Operational Product in the form of bailouts of Bank Indonesia.
\end{abstract}

Keywords: Islamic Finance, Gold Investment, Buy Pawn.

\section{PENDAHULUAN}

\section{A. Latar Belakang}

Islam merupakan agama yang besar. Agama yang berisikan nasihat dan peraturan yang bertujuan untuk mengatur kehidupan manusia agar sesuai dengan disiplin dan cita-cita agama yang mengarah kepada falah. ${ }^{2}$ Islam sebagai agama rahmatan lil-lamin berarti agama Islam berfungsi untuk memberikan keamanan kenyamanan bagi seluruh makhluk. Islam tidak pernah mempermasalahkan status yang disandang seseorang apakah ia muslim atau non-muslim, disinilah letak mendasar perbedaan agama Islam dengan yang lainnya. Islam merupakan agama yang tidak

1 Penulis adalah alumni Prodi Ekonomi Islam FIAI UII. E-mail anggoro_sugeng_uii@yahoo.co.id.

${ }^{2}$ Dalam pengertian literal, falah adalah kemuliaan dan kemenangan yaitu kemuliaan dan kemenangan dalam hidup baik dunia maupun akhirat. lihat Munrokhim Misanam, et.al., (2008), Ekonomi Islam, (Jakarta: PT Raja Grafindo Persada), h. 525. 
memarginalkan dan tidak mengeksklusifkan ${ }^{3}$ satu golongan karena Islam adalah agama bagi seluruh alam.Islam telah mengatur seluruh perkara dengan peraturannya yang jelas, tidak terkecuali masalah mu'amalah. Ketika kaum muslim berada dibawah pemerintahan khalifah yang menganut sistem Ekonomi Syariah, berbagai mu'amalah diatur. Perkara halal dan haram menjadi mercusuar pertimbangan dari setiap transaksi. Misalnya seseorang dilarang memasuki pasar untuk berdagang, hanya karena ia tidak memahami konsep mu'amalah, hal ini dilakukan tidak lain karena agar terhindar dari masalah riba. Seperti itulah Ekonomi Syariah mengatur dalam setiap tindak tanduk manusia dalam berniaga.

Namun hal itu semua berubah tatkala sistem khilafah ini runtuh, umat muslim dipaksa harus mengikuti konsep kapitalisme, ${ }^{4}$ yang memang tidak mengenal kata halal dan haram. Ini karena akar sistem kapitalisme adalah paham sekulerisme, ${ }^{5}$ yang mana agama tidak lagi menjadi pertimbangan dalam kehidupan, termasuk dalam bermuamalah. Walhasil kaum muslim hidup dari sistem Ekonomi yang jauh dari nilai keislaman, termasuk perbankan syariah. ${ }^{6}$

Saat ini perbankan syariah sendiri telah mengembangkan beberapa inovasi dan kreatifitas dalam beberapa produk unggulan. Sebut saja produk investasi emas yang amat digandrungi oleh kebanyakan orang. Inovasi dan kreatifitas ini kiranya menjadi suatu hal yang lazim adanya mengingat semakin berkembangnya zaman dan kecantikan dunia dengan teknologinya, akan tetapi perlu diingat bahwa inovasi dan kreatifitas tidak boleh melanggar dari nilai-nilai dasar Ekonomi Islam. ${ }^{7}$

Investasi berkebun emas merupakan sebuah investasi cerdas untuk menghasilkan keuntungan yang menggiurkan, menurut Rully Kustandar pengusaha asal bandung yang menciptakan metode ini. ${ }^{8}$ Investasi berkebun emas sendiri telah dijalankan beberapa bank syariah dengan tiga fitur pilihan, ada dengan gadai murni emas, kepemilikan logam mulia dan investasi emas yang kesemuanya ini sering dikenal dengan sebutan. Investasi ini mengklaim lebih menyilaukan hasilnya dari pada investasi emas biasa. Investasi emas sendiri boleh dibilang memainkan strategi investasi emas yang berbeda, dibanding investasi emas pada umumnya.?

Emas memang digdaya ${ }^{10}$ dan jika diinvestasikan pun nilainya terus naik. Investasi emas mulai dijadikan tren masa kini. Banyak orang tertarik untuk menggeluti

${ }^{3}$ Kamus Bahasa Indonesia, Kamus Pusat Bahasa, edisi XVI, (Jakarta: Pusat Bahasa,2008). Hal 918.

${ }^{4}$ Kapitalisme adalah sistem ekonomi dimana kepemilikan perorangan atas kekayaan diakui. Sumaji, et.al. (2006), Kamus Ekonomi,(ttp: wipress, 2006), Hal. 137.

${ }^{5}$ Kamus Besar Bahasa Indonesia, h.1287.

${ }^{6}$ Nur Chamid, (2010), Jejak Langkah Sejarah Pemikiran Ekonomi Islam, (Yogyakarta: Pustaka Pelajar).

${ }^{7}$ Munrokhim Misanam, Ekonomi Islam, hh. 58-65.

8 "Investasi Gadai Emas Syariah", Majalah Sharing, Edisi 38 Tahun IV, Februari 2010, h. 10.

${ }^{9}$ Ibid. h. 16. 
Anggoro Sugeng: Analisis Prinsip Ekonomi Islam Terhadap Operasional Produk Investasi...

investasi ini dan konon sudah banyak yang merasakan hasilnya. Di situs jejaring Facebook di akun Rully sendiri, terungkap beberapa kesaksian dari para pengikut investasi ini. Seperti Andy Wahyu Rizaldi yang mengaku hanya dalam waktu 3 bulan bisa membiakan modal awal emasnya sejumlah 50 gram menjadi 500 gram. Lalu Rieza Pahlevi yang mengaku mampu mengembangkan modal awal emasnya 10 gram menjadi 60 gram hanya dalam waktu satu minggu. Orang seperti Andy dan Rieza yang mencoba mencari peruntungan hidup lebih baik lewat investasi kebun emas ini semakin banyak. Kebun emas kini memang menjadi buah bibir dimanamana. ${ }^{11}$

Bukan merupakan suatu keanehan jika investasi ini banyak yang menggandrungi, mengingat emas sendiri dapat dikatakan zero inflation. Jadi ketika harga naik, harga emas akan cenderung meningkat. Selama ini harga emas cenderung setabil dan meningkat karena itu ketika kondisi Ekonomi memburuk atau terjadi ketidakpastian akan prospek perekonomian semua pihak akan cenderung memegang emas sebagai asetnya dibanding aset bentuk lainnya. ${ }^{12}$ Emas merupakan investasi teraman dan paling menguntungkan. Banyak orang merubah investasi dari sektor infrastruktur dialihkan ke emas. Tindakan ini benar meskipun sebagian orang memilih sektor infrastruktur sebagai instrumen utama.

Tercatat kenaikan harga emas paling fantastis terjadi pada tahun 2001 dimana pada saat yang sama mata uang kertas mengalami penurunan nilai. Proses kenaikan harga emas itu akan semakin dipercepat oleh laju inflasi dan abusing dollar AS saat itu.

\section{Tabel 1}

Perkembangan Harga emas Tahun 2000-2011 (kitco.com) ${ }^{13}$

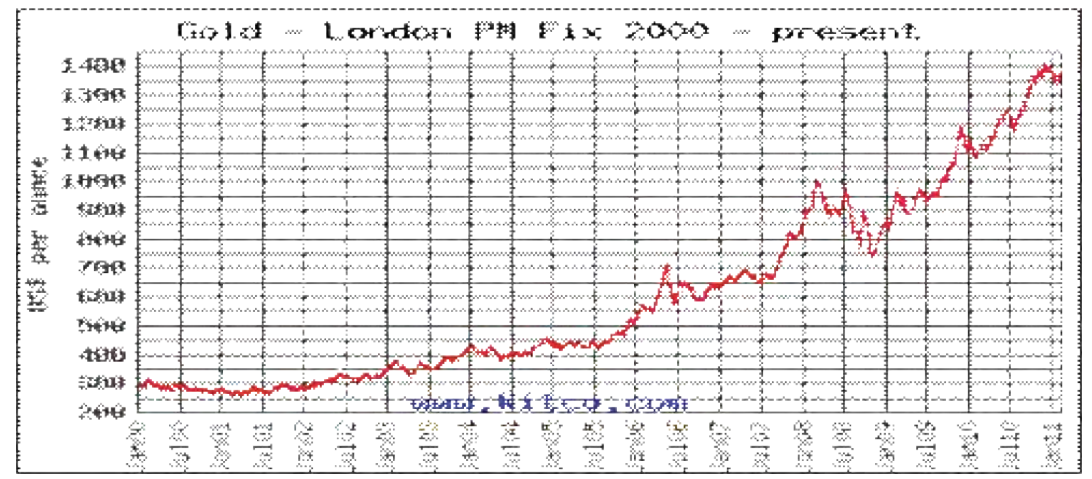

\footnotetext{
${ }^{10}$ Kamus Besar Bahasa Indonesia, h. 353.

${ }^{11}$ Menanam, Sharing, h. 16.

12 "Investasi Gadai Emas Syariah", Majalah Sharing, hh.18-19.

13 "Perkembangan: Harga Emas", dikutip dari www.kitco.com diakses 1 September 2011.
} 
Memang logam mulia bernama emas sepertinya tidak akan pernah lekang dimakan zaman. Kemuliaan dan kemilaunya tetap saja memukau termasuk bagi dunia investasi. Emas merupakan komoditas yang unik dan jumlahnya terbatas di dunia serta satu-satunya yang dapat ditambang diatas permukaan bumi. Emas juga merupakan alternatif uang kertas dengan daya beli yang abadi dan nilainya cenderung dipatok oleh pasar. ${ }^{14}$

Pilihan investasi emas saat ini tetap dinilai paling menguntungkan dibandingkan opsi yang lain mengingat sifatnya yang kebal inflasi. Investasi emas ibaratnya tidak ada matinya atau selalu menguntungkan. Berinvestasi emas sama sifatnya dengan menginvestasikan dana untuk membeli tanah dan properti di kotakota tertentu di Indonesia seperti Bali dan Yogyakarta yang harganya terus-menerus naik. Namun investasi emas juga ada beberapa kelemahannya. Calon investor juga harus mempertimbangkan banyak hal untuk menginvestasikan dananya dalam bentuk emas karena relatif tidak praktis dan sulit disimpan, beresiko tinggi, dicuri atau dirampok dan lain-lain. Selain itu bila penyimpanannya kurang baik memungkinkan terjadinya oksidasi dan perubahan warna. Khusus emas berbentuk koin kalau terjatuh sulit untuk di-treatment ulang dan bisa mengurangi harga. ${ }^{15}$

Dari ketiga produk investasi emas yang telah disebutkan diatas, bahwa produk terakhir ini yang akan dijadikan penelitian oleh penulis, dimana penulis akan melakukan analisa terhadap produk investasi emas, seperti halnya unsur gharar ${ }^{16}$ atau ketidakjelasan barang berupa emas pada saat berinvestasi, dalam arti pada saat seseorang akan berinvestasi. Apakah ia tidak bisa mengetahui barangnya atau hanya berupa surat ataupun kwitansi bahwa telah berinvestasi emas. Disamping itu adanya unsur maysir ${ }^{17}$ atau spekulasi, yakni apakah pada saat kita akan menjual kembali kita bermain dengan capital gain, berupa selisih harga beli dengan harga jual.

Selanjutnya terlepas dari konsep gharar dan maysir, masih ada sebab yang dapat menjadi penguat bahwa, dengan melakukan investasi emas secara besar-besaran akan mengakibatkan tidak berjalannya roda perekonomian. Hal ini terlihat karena uang yang diinvestasikan akan berhenti, tidak bisa digunakan dan tidak bisa dimanfaatkan untuk menjalankan roda perekonomian. Jika hal ini dilakukan, maka pihak yang membutuhkan dana tidak bisa menjalankan aktifitasnya. Seperti orangorang yang bergelut pada usaha mikro kecil dan menengah yang terkendala dengan

${ }^{14}$ Tanti Haikal, (2011), Panduan Cerdas \& Syar'i Investasi Syariah Dinar-Emas-Sukuk-Reksa Dana, (Yogyakarta: Araska), h. 60.

${ }^{15}$ Ibid, h. 62.

${ }^{16}$ Gharar secara bahasa berarti resiko atau juga ketidakpastian. Dengan kata lain, gharar terjadi karena seseorang tidak dapat mengetahui kemungkinan kejadian sesuatu sehingga bersifat perjudian atau game of chance. Lihat ibid. dan Munrokim Misanam, et.al., h. 526.

${ }^{17}$ Maysir atau spekulasi adalah usaha memperoleh laba dengan resiko yang relatif besar berdasarkan perkiraan akan terjadi perubahan harga. Dalam pengertian umumnya adalah prihal membeli atau menjual sesuatu yang mendatangkan keuntungan besar. Sumadji, kamus, Hal 606. 
Anggoro Sugeng: Analisis Prinsip Ekonomi Islam Terhadap Operasional Produk Investasi...

modal. Apabila UMKM ${ }^{18}$ dan sejenisnya tidak bisa menjalankan roda perekonomian, maka pendapatan akan berkurang. Hal ini akan mengakibatkan makin banyaknya masyarakat miskin, karena sulit untuk melakukan usaha. Dan hal ini pula yang selalu menjadi permasalahan di hampir setiap negara.

Selain itu pula apabila hal ini dilakukan produk ini maka makin banyak pihak yang menjerit karena susahnya mendapatkan rejeki, Sedangkan Islam sendiri telah menggambarkan bahwa adanya kewajiban bagi orang kaya untuk membantu orang miskin. Allah SWT berfirman:

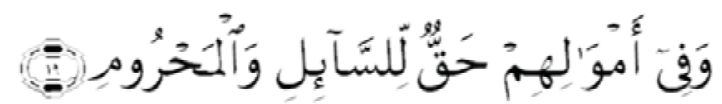

Artinya: Dan pada harta-harta mereka ada hak untuk orang miskin yang meminta dan orang miskin yang tidak mendapat bagian. ${ }^{19}$ QS. Al-Dzariyat (51): 19 .

Dalam keterangan lain disebutkan yang intinya "tidak dinamakan orang yang beriman jika melihat tetangganya hidup dalam kesusahan sedangkan ia hidup dengan bergelimang harta" sekali lagi apabila hal ini masih dilakukan, maka akan melanggar konsep Ekonomi Syariah yakni rahmatan lil-lamin. Dengan beberapa alasan inilah kiranya penelitian ini menjadi penting dan menarik untuk diangkat, mengingat investasi ini digandrungi oleh mayoritas orang dan terdapat beberapa faktor yang bersentuhan maupun bersinggungan dengan ketidaksesuaian produk investasi emas. Berdasarkan ilustrasi diatas, maka penulis tertarik untuk meneliti sekaligus menganalisa produk investasi emas pada Perbankan Syariah.

\section{TINJAUAN PUSTAKA DAN LANDASAN TEORI}

\section{A. Tinjauan Pustaka}

Pembicaraan tentang investasi emas sudah lama dimulai dan telah banyak dilakukan oleh beberapa kalangan. Hal ini dibuktikan, dengan banyaknya penelitian lepas yang diterbitkan, walaupun belum terdapat peraturan yang mengikat serta memayungi konsep investasi emas Beli Gadai. Namun sejauh penelusuran penulis, pembahasan mengenai konsep tinjauan Ekonomi Islam terhadap investasi emas pada Perbankan Syariah belum banyak dilakukan. ${ }^{20}$ Adapun beberapa penelitian tersebut adalah sebagai berikut:

${ }^{18} \mathrm{UMKM}$ adalah sebuah istilah yang mengacu ke jenis usaha kecil yang memiliki kekayaan bersih paling banyak Rp 200.000.000 tidak termasuk tanah dan bangunan tempat usaha. Dan usaha yang berdiri sendiri. Dikutip dari http://id.wikipedia.org diakses 14 Desember 2011.

${ }^{19}$ Orang miskin yang tidak mendapat bagian maksudnya ialah orang miskin yang tidak meminta-minta. QS. Al-Dzariyat (51): 19.

${ }^{20}$ Tanti Haikal, (2011), h. 60. 
Penelitian Hamzah Gufron pada $2011^{21}$ yang bertujuan untuk lebih memahami tentang produk yang ditawarkan oleh Bank Sumut Syariah cabang Medan tentang Produk qardh dengan Gadai Emas. Lebih lanjut ia menjelaskan bahwa faktor promosi, prosedur pencairan pinjaman, dan harga taksiran barang memiliki pengaruh positif dan signifikan terhadap minat nasabah untuk menggunakan Produk Bank Sumut Syariah cabang Medan. Dengan kesimpulannya bahwa faktor Promosi merupakan faktor yang paling utama dalam mempengaruhi minat nasabah untuk menggunakan Produk qardh dengan Gadai Emas di PT. Bank sumut Syariah Cabang Medan.

Penelitian Eka Maya Irla Yulifa pada $2011^{22}$ memaparkan bahwa Bank Syariah merupakan lembaga keuangan yang kegiatannya menghimpun dana dari masyarakat dan menyalurkannya kembali kepada masyarakat. BNI Syariah Kantor Cabang Surakarta merupakan salah satu bank yang beroperasi sesuai dengan prinsip Syariah. Kegiatan operasional Bank BNI Syariah yaitu menghimpun dana dari masyarakat yang berupa giro, tabungan, dan deposito, lalu menyalurkannya kembali dana tersebut kepada masyarakat dalam bentuk pembiayaan. Penelitian ini membahas permasalahan mengenai bagaimana prosedur pelaksanaan pembiayaan dan faktor yang membuat produk Gadai Emas Syariah bermasalah pada PT. Bank BNI Syariah Kantor Cabang Surakarta. Dalam pembahasan ia menyimpulkan bahwa prosedur pelaksanaan pembiayaan produk Gadai Emas Syariah pada PT. Bank BNI Syariah Kantor Cabang Surakarta ada beberapa prosedur, yaitu prosedur pemberian pembiayaan Rabn, prosedur pelunasan Rabn, prosedur ulang gadai, dan prosedur penjualan barang jaminan (lelang). Dalam pembiayaan ini terdapat beberapa faktor yang menyebabkan pembiayaan bermasalah. Sehingga penulis memberikan saran bahwa dalam pelaksanaan pembiayaan sebaiknya Bank tetap mempertahankan prinsip Syariah dan Bank harus lebih teliti dalam pemberian pembiayaan dan memutuskan layak tidaknya pembiayaan dan Bank dapat menjaga kepercayaan nasabah pembiayaan Gadai Emas Syariah.

Penelitian yang dilakukan oleh Sunarya pada $2005^{23}$ lebih memprioritaskan tentang rancangan sistem informasi gadai emas melalui komputerisasi dengan tidak melupakan analisa gadai emas. Penelitian yang dilakukanya merupakan suatu usaha tanggap terhadap operasional produk gadai emas di Bank Jabar dengan sedikit sentuhan sistem informasi gadai emas. Memang harus diakui Sunarya merupakan

${ }^{21}$ Hamzah Gufron, (2011), "Faktor-faktor yang mempengaruhi Minat Nasabah dalam Produk Qardh dengan Gadai EMAS di PT. Bank Sumut Syariah Cabang Medan”, Skripsi, Universitas Sumatra Utara, Tidak Dipublikasikan.

${ }^{22}$ Eka Maya Irla Yulifa, (2011), "Prosedur Pembiayaan Islamic Banking (IB) Produk Gadai Emas Syariah pada PT. Bank BNI Syariah Kantor Cabang Surakarta", Skripsi, Universitas Sebelas Maret, Tidak Dipublikasikan.

${ }^{23}$ Sunarya, (2005), "Perencanaan Sistem Informasi Gadai Emas Syariah pada Bank Jabar Kantor Cabang Syariah Bandung”, Skripsi, Universitas Komputer Indonesia, Tidak Dipublikasikan. 
Anggoro Sugeng: Analisis Prinsip Ekonomi Islam Terhadap Operasional Produk Investasi...

peneliti dari UNIKOM dimana konsentrasi studinya terletak pada konsep informatika. Jadi tidak salah kiranya jika ia meneliti tentang konsep Gadai emas menurut sudut pandang keahliannya.Adapun perkara yang menjadi acuan dalam penelitian kali ini berupa operasional produk investasi emas dan pandangan ekonomi Islam tentang investasi emas.

\section{B. Landasan Teori}

\section{Prinsip-prinsip Ekonomi Islam dalam Investasi}

Prinsip-prinsip Islam dalam muamalah yang harus diperhatikan oleh pelaku investasi syariah (pihak terkait) adalah:

a. Tidak mencari rizki pada hal yang haram, baik dari segi dzatnya maupun cara mendapatkanya serta tidak menggunakannya untuk hal-hal yang haram.

b. Tidak mendzalimi dan tidak didzalimi.

c. Keadilan pendistribusian kemakmuran.

d. Transaksi dilakukan atas dasar rida sama rida.

e. Tidak ada unsur riba, maysir dan gharar.

Berdasarkan keterangan diatas, maka kegiatan investasi mengacu pada prinsip ekonomi islam yang berlaku. Perputaran modal pada kegiatan ini tidak boleh disalurkan kepada jenis industri yang melakukan kegiatan-kegiatan yang diharamkan. Pembelian saham misalnya atas saham pabrik minuman keras, pembangunan penginapan untuk prostitusi dan lainnya yang bertentangan dengan syariah berarti diharamkan. ${ }^{24}$

Semua transaksi yang terjadi pada konsep ini harus atas dasar suka sama suka, tidak ada unsur pemaksaan, tidak ada pihak yang didzalimi atau mendzalimi. Seperti goreng-menggoreng saham pada pasar modal. Tidak ada unsur riba, tidak bersifat spekulasi atau judi, dan semua transaksi harus transparan dan diharamkan adanya insider trading. ${ }^{25}$

\section{Beli Gadai}

Produk "beli gadai" pada dasarnya adalah bentuk dukungan penuh bank syariah terhadap formula kebun emas. Perbedaanya, bila pada formula kebun emas nasabah harus melakukan transaksi mondar-mandir antara bank syariah dengan toko emas untuk berkali-kali melakukan transaksi gadai kemudian beli lagi, gadai lagi dan beli

\footnotetext{
${ }^{24}$ Inggrid Tan, Bisnis dan Investasi Sistem Syariah, (Yogyakarta: Universitas Atma Jaya Yogyakarta, 2009), hh. 15-16.

${ }^{25}$ Insider Trading (perdagangan orang dalam) adalah perdagangan yang menggunakan informasi orang dalam yaitu informasi-informasi yang tidak diketahui oleh umum untuk mendapatkan suatu keuntungan dalam perdagangan aktiva. Melakukan perdagangan tersebut dianggap sebagai tindakan ilegal. Sumadji, Kamus, h. 387.
} 
lagi, tetapi pada produk beli gadai, bank syariah seolah-olah menjadi mediator antara nasabah yang berminat membeli emas dengan toko emas.

Kalau dianalogikan produk lain, yakni dana talangan haji, bank syariah menjadi mediator antara calon jamaah haji dengan peyedia jasa penyelenggara haji. Perbedaannya, dana talangan haji diluncurkan sebagai prduk yang eksplisit dipromosikan, sedangkan beli gadai masih dilakukan secara implisit atau "diamdiam".Diam-diamnya bank syariah merupakan bentuk kerendahhatian bank syariah dalam proses dukungannya menggiatkan dan mengkampanyekan penggunaan emas, yang merupakan kewajiban sebuah institusi penggiat ekonomi Islam, namun tidak boleh bersinggungan dengan mereduksi keberadaan rupiah dan mata uang kertas, karena bank syariah hidup di negara yang bukan bermata uang emas.

Skema beli gadai emas secara sederhana dapat dijelaskan sebagai berikut. Bank syariah mendampingi nasabah yang ingin memiliki emas berkomunikasi dengan toko emas. Melalui mekanisme gadai, bank dapat memberikan dana talangan 85\% hingga 90\% dengan catatan emas yang sudah dibeli digadaikan di bank tersebut. Emas dapat dibawa pulang oleh nasabah setelah melunasi dana cadangan tersebut.

Keuntungannya, nasabah dapat melunasi emas dalam jangka waktu tertentu, tanpa terpengaruh kenaikan harga emas. Dan keuntungan yang bersifat investatif, sekalipun emas itu tidak bertujuan untuk dimiliki oleh nasabah, nasabah dapat memperoleh keuntungan atas kenaikan harga emas dikurangi ujrah atau biaya titip atas emas yang digadai. ${ }^{26}$

\section{Standard Operating Procedure (SOP) Dana Talangan Gadai Emas}

Dengan berkembangnya industri perbankan syariah, khususnya sektor emas yang menjadi produk khusus perbankan syariah, ternyata masih banyak sekali pekerjaan rumah yang harus diselesaikan oleh bank syariah terutama mengenai dana talangan yang kurang sesuai dengan peraturan dari Bank Indonesia. Lebih lanjut adanya SOP dana talangan dari BI merupakan suatu bentuk aturan dan perhatian khusus dari Bank Indonesia terhadap industri perbankan syariah.

Bank Indonesia selaku pemangku kebijakan bagi seluruh bank di nusantara mengerti benar tentang adanya inovasi dan kreatifitas dalam bidang emas. Tidak salah kiranya jika bank Indonesia memiliki standar aturan tentang emas itu sendiri. Meninjau lebih jauh peraturan BI tentang dana talangan yang mana aturannya adalah tidak boleh dari 80\%, hal ini merupakan salah satu upaya dari Bank Indonesia sendiri untuk mengatur perputaran keuangan serta menjaga stabilitas keuangan suatu bank sebagai sikap kehati-hatian perbankan syariah.

Bank Indonesia baru-baru ini merampungkan kajian atas standard operating procedure bisnis gadai emas yang diserahkan bank syariah. Dari evaluasi itu BI menilai

\footnotetext{
${ }^{26}$ Haikal, Panduan, hh. 85-86.
} 
hanya dua bank syariah yang sudah memenuhi ekspektasi. Selebihnya belum sesuai standar yang diinginkan bank sentral. Menurut Mulya Effendi Siregar, Direktur Direktorat Perbankan Syariah BI, bank-bank tersebut harus menyesuaikan SOP lagi. Namun ia tidak bersedia menyebutkan identitas bank mana saja yang sudah memenuhi SOP maupun yang belum. Meskipun belum memenuhi SOP, Bank Indonesia tidak akan melarang bank bersangkutan menjalankan bisnis gadai emas. Regulator hanya mengembalikan SOP tersebut ke bank agar direvisi lagi. Jika sampai akhir tahun ini bank masih gagal menyesuaikan diri, BI akan bertindak dengan menyusun regulasi dan SOP sendiri. Bank tidak punya pilihan selain mematuhinya.

Sebagai gambaran, dari 34 bank syariah dan unit usaha syariah hanya delapan bank yang menawarkan gadai emas dan produk lain berbasis emas. Sebelum ada perintah menyusun ulang SOP bank syariah banyak menawarkan gadai dengan loan to value di bawah $80 \%$ dan porsinya di atas $10 \%$ dari total pembiayaan. Kondisi ini jika tidak ditata ulang bisa membahayakan industri perbankan syariah sektor emas. BI menjadikan LTV dan porsi pembiayaan tersebut sebagai acuan penyusunan SOP. Akad transaksinya adalah qardh. Acuan lain bank harus membentuk pencadangan dan menanggalkan istilah gadai emas. Dengan demikian, jika bank tidak memasukkan hal tersebut dalam SOP, maka Bank Indonesia akan mengaturnya. ${ }^{27}$

\section{METODE PENELITIAN}

\section{A. Jenis Penelitian}

Penelitian ini adalah penelitian lapangan, dimana masalah yang diajukan di dalamnya ditentukan pada masalah operasional. Jenis penelitian ini adalah penelitian kualitatif. Berdasarkan rangkaian teori tentang penelitian kualitatif tersebut, peneliti berkeyakinan untuk menggunakan metode penelitian deskripif, karena pada penelitian ini memusatkan pada deskripsi data yang berupa kalimat-kalimat yang mendalam, yang berasal dari informan dan prilaku berbagai hal yang ada relevansinya dengan aplikasi skim beli gadai menurut prinsip ekonomi Islam.

\section{B. Sifat Penelitian}

Penelitian yang dilakukan bersifat evaluation research, yang menganalisa dan menyajikan fakta secara sistemik sehingga dapat lebih mudah untuk difahami dan disimpulkan berdasarkan pedoman yang berlaku. Kesimpulan yang diberikan selalu jelas dasar faktanya sehingga semuanya selalu dapat dikembalikan langsung kepada data yang diperoleh. Penelitian ini dilakukan untuk mengetahui keadaan sebenarnya yang ada sekarang.

${ }^{27}$ Standard Operating Procedure (SOP) Dana Talangan Gadai Emas di perbankan syariah.dikutip dari http://www.kontan.co.id diakses 3 Maret 2012. 
Anggoro Sugeng: Analisis Prinsip Ekonomi Islam Terbadap Operasional Produk Investasi...

\section{Lokasi Penelitian}

Penelitian ini mengangkat studi kasus tentang operasional produk investasi emas pada Perbankan Syariah. Adapun alasan dipilihnya perbankan syariah karena pada saat awal penelitian penulis mengetahui bahwa perbankan syariah telah memiliki produk yang menjadi pusat penelitian yang dilakukan penulis.

\section{Sumber Data}

Ada dua jenis data yang digunakan yakni data primer dan sekunder. Data primer adalah data yang diperoleh langsung dari subyeknya, diamati dan dicatat untuk pertama kalinya. Dalam penelitian ini data primer diperoleh langsung dari lokasi penelitian atau disebut juga data lapangan, dalam hal ini Perbankan Syariah. Sedangkan data sekunder adalah data yang diperoleh tidak secara langsung dari objek penelitian tetapi dari pihak lain yang mempunyai informasi data yang diperlukan atau literatur yang berhubungan dengan obyek penelitian. Hal ini penulis lakukan dengan membaca, mempelajari buku-buku yang memiliki korelasi dengan penelitian kali ini.

\section{E. Teknik Pengumpulan Data}

\section{Wawancara}

Model wawancara ini adalah dengan mengajukan pertanyaan secara tidak terstruktur namun tetap mengacu pada materi penelitian atau pokok masalah tertentu.

\section{Studi Kepustakaan (library research)}

Dalam hal ini peneliti menggali teori yang telah berkembang dalam bidang ilmu yang berhubungan dengan obyek penelitian. Mencari metode serta teknik penelitian baik dalam pengumpulan data maupun dalam menganalisis data yang telah dibahas sebelumnya. Untuk memperoleh orientasi yang lebih luas dalam permasalahan yang dipilih serta menghindari duplikasi-duplikasi yang tidak diinginkan.

\section{Observasi/Pengamatan}

Observasi merupakan aktifitas pencatatan fenomena yang dilakukan secara sistematis. Observasi ini dilakukan untuk mencari data yang berhubungan dengan hasil-hasil dilapangan. Teknik ini biasanya disebut observasi partisipasi pasif yang dilakukan secara formal dan informal untuk mengamati pokok permasalahan yang diteliti.

\section{Dokumentasi}

Dokumen merupakan catatan peristiwa yang sudah berlalu. Dokumen dapat berupa tulisan, gambar atau karya-karya monumental seseorang. Didalam melaksanakan metode dokumentasi, penulis meneliti benda-benda tertulis seperti 
Anggoro Sugeng: Analisis Prinsip Ekonomi Islam Terhadap Operasional Produk Investasi...

notulen, catatan, surat kabar, buku, kwitansi dan lain-lain yang dianggap penting dalam penelitian.

\section{F. Teknik Analisis Data}

Data yang diperoleh dalam penelitian ini berupa data primer dan data sekunder disajikan dalam uraian yang sesuai dengan hasil penelitian, kemudian disusun secara teratur. Data yang disajikan mula-mula dalam bentuk gambaran, kemudian dianalisis dan berakhir dengan penarikan kesimpulan. Dalam analisis data yakni data yang diperoleh dari hasil penelitian, baik data dari hasil wawancara, library research, observasi maupun dari telaah dokumen, disusun secara sistematis, kemudian dianalisis dengan menggunakan metode:

\section{Analisis Kualitatif}

Analisis kualitatif yaitu penganalisisan data sekunder, pertama-tama dilakukan inventarisasi terhadap norma atau prinsip-prinsip terkait dengan perbankan syariah. Dalam hal ini dikumpulkan asas-asas terkait permasalahanya yaitu tentang operasional produk investasi emas untuk kemudian diorganisir kedalam suatu sistem yang komprehensif.

\section{Analisis Deskriptif}

Analisis deskriptif yaitu penganalisaan data primer secara mendalam dengan menghubungkan pada data sekunder sehingga diperoleh gambaran secara jelas dan rinci fenomena yang menjadi pokok bahasan tanpa melakukan perhitungan secara statistik.

\section{ANALISIS DAN PEMBAHASAN}

Pada penelitian ini penulis melakukan analisis apakah prosedur pelalaksanaan investasi emas di perbankan Syariah X, dengan menggunakan skim beli gadai telah sesuai dengan pandangan ekonomi Islam atau fiqh dan Fatwa Dewan Syariah Nasional terkait transaksi ini. Analisis ini difokuskan pada tujuan investasi emas, mekanisme dan persyaratan nasabah pemohon, jangka waktu investasi emas, keuntungan investasi emas, keberadaan emas atau posisi emas saat investasi emas. Dalam prakteknya perbankan telah memiliki kerjasama dengan beberapa toko emas di sekitar, dengan adanya kerjasama ini dapat mempermudah kinerja antara bank dengan nasabah yang menginginkan emas.

\section{A. Tujuan Investasi Emas}

Transaksi investasi emas ini memiliki beberapa tujuan khusus yakni diantaranya adalah untuk menjaga nilai serta tujuan investasi jangka pendek. Jika merujuk kepada kegunaan emas sendiri, tidak salah jika komoditi ini dijadikan suatu barang simpanan, 
Anggoro Sugeng: Analisis Prinsip Ekonomi Islam Terbadap Operasional Produk Investasi...

tentunya dengan alasan bahwa emas mudah disimpan dan tergolong barang liquid yang dengan mudah dapat dicairkan sewaktu-waktu.

Hal ini sesuai dengan Fatwa Dewan Syariah Nasional Majelis Ulama Indonesia No: 26/DSN-MUI/III/2002 tentang Rahn Emas, pada ketentuan umum Rabn Emas ini dijelaskan tujuan Investasi emas bahwa masyarakat pada umumnya telah lazim menjadikan emas sebagai barang berharga yang disimpan dan menjadikannya objek Rabn sebagai jaminan utang untuk mendapatkan pinjaman uang. Dari sini bisa dipahami yakni emas dijadikan barang berharga yang layak untuk disimpan dan bukan lagi menjadi rahasia umum atas legalitas emas sebagai barang berharga dan layak untuk menjadi acuan investasi alternatif di zaman modern.

Adapun maksud emas menjaga nilai adalah emas dijadikan acuan dimasa mendatang, jadi jika dikaitkan dengan investasi emas menjaga nilai adalah pola investasi yang ditujukan untuk menjaga nilai uang. Sebagai contoh Pak Rozaq mempunyai uang Rp2 juta, kemudian membeli emas, beberapa tahun kemudian nilai emas akan naik seiring dengan terus naiknya inflasi mata uang. Jadi, dengan emas setidaknya nilai uang pak budi yang sebesar Rp2 juta itu akan sama dengan nilai mata uang di masa mendatang beberapa tahun kemudian. Sedangkan investasi emas jangka pendek di perbankan bisa dipahami sebagai pola investasi emas dengan membeli emas pada saat harga murah dan menjualnya pada saat harga emas mahal. Seorang nasabah yang melakukan investasi emas jangka pendek akan mendapatkan keuntungan dengan adanya selisih harga beli dan harga jual atau dikenal dengan istilah profit margin. Kiranya tujuan investasi JAPEN ini menjadi perhatian khusus bagi perbankan syariah yang menggunakan transaksi investasi emas, disamping emas sendiri merupakan tergolong barang ribawi. Kiranya hal ini sesuai dengan larangan Allah SWT dalam Al-Quran yang berbunyi:

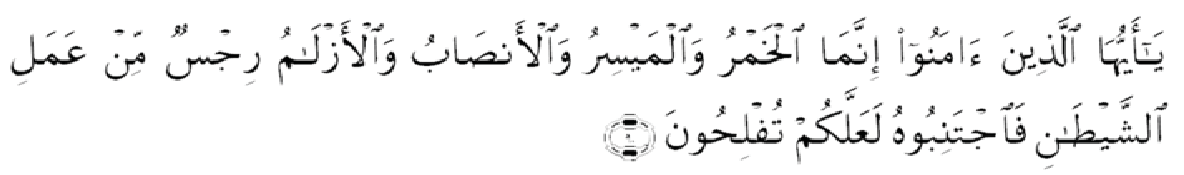

Artinya: hai orang-orang yang beriman, sesunggubnya minuman khamar, berjudi, (berkorban untuk) berhala, mengundi nasib dengan panah, adalab termasuk perbuatan syaitan. Maka jaubilah perbuatan tersebut agar kamu mendapatkan keberuntungan. ${ }^{28}$

Ayat diatas menunjukkan haramnya perbuatan maysir dan qimar dalam mu'amalah. Maysir adalah setiap mu'amalah yang masuk kedalamnya setelah mengeluarkan biaya dengan dua kemungkinan yakni untung dan rugi. Sedangkan qimar menurut sebagian ulama adalah sama dengan maysir, dan menurut kesepakatan ulama lainya bahwa qimar hanya pada mu'amalah yang berbentuk perlombaan dan pertaruhan.

${ }^{28} \mathrm{QS}$ Al-Maidah (5): 90. 
Anggoro Sugeng: Analisis Prinsip Ekonomi Islam Terhadap Operasional Produk Investasi...

\section{B. Mekanisme Investasi Emas}

Proses investasi emas Perbankan Syariah X berlangsung mudah dan cepat, hal ini diakui oleh seorang debitur yang pernah mengajukan investasi emas bahwa prosesnya lebih cepat dan biaya gadai lebih murah dibandingkan perum pegadaian. Adapun mekanisme investasi emas dengan Skim Beli Gadai secara sederhana dapat dijelaskan sebagai berikut: Nasabah mengajukan keinginan untuk investasi emas, Bank syariah mendampingi nasabah dalam proses investasi emas, Melalui mekanisme gadai bank dapat memberikan dana talangan $85 \%$ hingga 90\%, Dengan catatan emas yang sudah dibeli digadaikan di bank tersebut, Emas dapat dibawa pulang oleh nasabah setelah melunasi dana cadangan tersebut.

Jika dirujuk lebih lanjut, perbankan syariah memberikan dana talangan kepada nasabah dengan ketentuan yang mudah sampai $90 \%$, Seolah-olah perbankan syariah tidak memperhatikan kehati-hatian dalam memilih calon nasabah. Dengan alibi bahwa adanya emas yang digadaikan di bank syariah merupakan suatu jaminan atas dana talangan yang telah dikeluarkan. Maka dapat dipahami dengan adanya jaminan ini kecil kemungkinan akan adanya sengketa dari investasi emas. Jika terjadi sengketa maka emas yang digadaikan bisa diliquidkan atau dijual, termasuk pada saat nasabah membutuhkan dana secara mendadak.Sedangkan menurut peraturan BI tentang dana talangan yang mana aturannya adalah tidak boleh lebih dari $80 \%$, hal ini merupakan salah satu upaya dari Bank Indonesia sendiri untuk mengatur perputaran keuangan serta menjaga stabilitas keuangan suatu bank sebagai sikap kehati-hatian bagi perbankan syariah dan Bank Indonesia akan menertibkan peraturanStandard Operating Procedure (SOP) Dana Talangan Gadai Emas bagi perbankan syariah yang belum sesuai.

\section{Jangka Waktu Investasi Emas}

Jangka waktu investasi emas adalah 4 bulan, karena investasi ini merupakan investasi jangka pendek, tetapi tidak menutup kemungkinan untuk diperpanjang setelah masa kontrak selesai. Investasi ini hak sepenuhnya dimiliki oleh nasabah, baik ia ingin memiliki, investasi jangka pendek saja dan termasuk masalah waktu investasi emas juga. Pihak bank tidak memiliki wewenang untuk mempengaruhi nasabah mengenai jangka waktu Investasi emas ini, termasuk didalamnya waktu yang tepat melempar emas yang telah dibeli untuk dijual ke toko emas. Jadi investasi emas ini berjangka waktu 4 bulan, dan nasabah memiliki hak untuk memperpanjang atau menyelesaikan sebelum waktu yang telah ditentukan.

\section{Keuntungan Investasi Emas}

Adapun keuntungan dari investasi emas ini adalah adanya perbedaan harga atau kenaikan harga emas, yakni adanya perbedaaan atau kenaikan antara harga beli dengan harga jual emas itu sendiri. Contoh dalam 2 sampai 10 hari saja apabila 
sudah terjadi kenaikan harga emas maka pasti akan mendapatkan keuntungan. Inilah yang menjadi keuntungan investasi dengan emas, dengan harga yang selalu naik dari hari-hari sebelumnya. Di samping itu emas berguna untuk menjaga nilai agar tidak merosot terkena inflasi. Adapun keuntungan bagi bank sendiri adalah adanya biaya atau ujrah atas emas yang digadaikan dan disimpan di bank syariah.

Jika kita meninjau ulang terhadap pola keuntungan dari investasi emas dimana keuntungan investasi ini berupa jangka pendek yakni adanya selisih antara harga beli dengan harga jual. Disini ada keleluasaan nasabah untuk menggoreng harga emas, kapan nasabah membeli emas dan kapan nasabah menjualnya. Dengan ini kiranya jelas pola investasi emas ini bermain pada ranah spekulatif, karena hanya dengan keuntungan yang diperoleh dari selisih harga beli dengan harga jual lah nasabah mendapatkan keuntungan dengan sendirinya. Begitu pula jika saat emas dinanti kenaikannya, sedangkan harga emas semakin lesu maka mau tidak mau, nasabah tetap menggadaikan emasnya di perbankan sampai harga emas menjulang tinggi, kecuali pada saat-saat tertentu yang mengharuskan nasabah untuk menjual emas yang digadaikannya.

Konsep seperti diatas lebih dikenal dengan sebutan spekulatif atau maysir, yang secara umum menggambarkan adanya keuntungan tanpa adanya usaha riil untuk mendapatkan keuntungan tersebut. Memang pada hakikatnya pola investasi adalah suatu pola bisnis yang ingin mendapatkan keuntungan di masa yang akan datang. Tidak salah jika investasi lebih menginginkan adanya keuntungan di masa depan, tetapi tentunya kesemuanya ini diiringi dengan usaha riil yang jelas, bukan hanya mengharapkan adanya kenaikan dari harga emas.

Dalam prinsip ekonomi islam berkenaan dengan konsep investasi emas yakni tidak adanya larangan berupa pola investasi emas apabila hal itu tetap mengacu pada prinsip islam. Tetapi jika hal itu telah melampaui batasan yang diberikan oleh prinsip islam, maka hal itu harus ditinggalkan. Adapun unsur-unsur yang dilarang dalam transaksi diantaranya: perniagaan barang-barang yang haram, bunga/riba, perjudian atau spekulasi yang disengaja dan ketidaksejalsan serta manipulatif (gharar). Dengan adanya batasan dalam prinsip ekonomi islam diatas kiranya jelas sekali pola investasi yang mengandung unsur spekulatif merupakan sesuatu yang dilarang dalam islam. Dalam basic kebijakan ekonomi islam pun dijelaskan secara tegas akan larangan riba, pelarangan gharar, barang-barang yang haram dan pentingnya pelembagaan zakat dalam kebijakan yang diberikan oleh ekonomi islam.

Jika menilik sejenak tentang konsep maqasid syariah berkenaan dengan konsep investasi yang spekulatif akan menyebabkan adanya ketidakadilan, yang mana akan terjadinya gap atau kesenjangan pihak investasi spekulatif dengan para pekerja sektor riil. Hal ini jelas mengakibatkan ketidakadilan dimana seorang investor dengan mudahnya memperoleh uang sedangkan pihak yang semangat bekerja hanya mendapatkan uang yang kurang sepadan dengan apa yang dilakukan. 
Jika melihat lebih dalam lagi dari nilai-nilai dasar ekonomi islam yang terdapat konsep adil dalam formulasi nilai-nilai dasar ekonomi islam. Adapun keadilan yang dimaksud disini berupa nilai turunan yang berasal darinya salah satunya adalah persamaan kompensasi. Persamaan kompensasi adalah pengertian adil yang paling umum, yaitu bahwa seseorang harus memberikan kompensasi yang sepadan kepada pihak lain sesuai dengan pengorbanan yang dilakukan. Pengorbanan yang telah dilakukan inilah yang menimbulkan hak pada seseorang yang telah melakukan pengorbanan untuk memperoleh balasan yang seimbang dengan pengorbanannya. ${ }^{29}$

\section{E. Barang Agunan dalam Investasi Emas}

Perbankan Syariah X menetapkan adanya transaksi gadai atas fasilitas dana talangan bagi jual beli emas dalam transaksi investasi emas. Mengingat hubungan antara nasabah dengan bank bersifat gadai, maka kedua pihak harus memiliki rasa tanggung jawab satu sama lain. Perbankan selaku pihak yang diamanahi emas hendaknya menjaga agar emas itu tetap aman, sedangkan nasabah harus memenuhi janjinya sesuai akad yang tertera di awal.

Agunan yang digadaikan di Perbankan SyariahX berasal dari emas yang dibeli oleh investor dengan uang muka dan dana talangan dari bank, yang dimaksudkan untuk mengikat nasabah agar ia serius dalam mengemban amanah dan tanggung jawab serta menjalankan komitmen yang telah disepakati. Meskipun secara teori para fuqaha berpendapat bahwa pada prinsipnya tidak perlu dan tidak boleh mensyaratkan agunan sebagai jaminan, akan tetapi untuk menghindari hal-hal yang tidak diinginkan, maka perbankan boleh menahan emas sampai nasabah mampu melunasi secara utuh kekurangan uang dalam investasi emas. Hal ini sama dengan keputusan Fatwa No: 25/DSN-MUI/III/2002 butir 1 yang berbunyi: murtabin berhak menahan marbun sampai semua utang rabin dilunasi.

Menurut penulis, adanya agunan yang dipersyaratkan oleh Perbankan Syariah kepada nasabah investor emas itu boleh bahkan lebih mengarah kepada suatu kewajiban atau perlu. Apa lagi dipersyaratkannya agunan ini bukan berarti karena tidak percaya kepada investor, melainkan sebagai salah satu bentuk tanggung jawab bank dalam menjaga keamanan dana pihak ketiga yang dititipkan kepada bank untuk dikelola dan dikembangkan melalui bisnis yang dijalankan oleh bank.

\section{KESIMPULAN DAN SARAN}

\section{A. Kesimpulan}

Dari hasil penelitian dan analisis data yang dilakukan penulis terhadap aplikasi Investasi Emas Perbankan Syariah X, maka dapat diambil kesimpulan yang merupakan jawaban dari permasalahan dalam penelitian ini, yaitu:

${ }^{29}$ Munrokhim Misanam, et.al., (2008), h. 59. 
Anggoro Sugeng: Analisis Prinsip Ekonomi Islam Terbadap Operasional Produk Investasi...

1. Oprasional produk Investasi Emas merupakan suatu investasi yang bisa dilakukan oleh pihak manapun, yang mana nasabah mengajukan keinginan kepada bank syariah dengan memberikan uang muka untuk membeli emas yang dibantu oleh dana talangan dari bank serta emas yang sudah dibeli harus digadaikan kepada bank. Adapun peran bank syariah sebagai mediator penghubung antara bank dan nasabah untuk membeli emas.

2. Secara umum aplikasi Investasi Emas merujuk kepada prinsip Ekonomi Islam yang mana masih terdapat beberapa ketidaksyariahan dari akad Investasi emas, diantaranya adalah gharar atau ketidakjelasan emas saat transaksi, maysir atau spekulasi berupa selisih harga beli dengan harga jual yang tidak diketahui yang dilakukan oleh pihak nasabah dan adanya dana talangan yang terlalu besar mencapai $90 \%$.

\section{B. Saran}

Berdasarkan hasil penelitian, analisis dan pembahasan, penulis memberikan saran kepada Perbankan Syariah X secara khusus dan instansi pengawas secara umum sebagai berikut:

1. Adanya Investasi Emas ini merupakan suatu akad yang belum terdapat payung hukum yang jelas, kiranya pihak terkait bisa mengkaji ulang, membahas, melakukan konsolidasi internal terkait eksistensi dari akad ini serta dapat menentukan lebih dini, apakah akad ini sesuai dengan syariat atau tidak.

2. Adanya inovasi dan kreatifitas merupakan suatu yang lazim nampaknya di dunia modern ini, tetapi hendaknya inovasi dan kreatifitas ini tetap mengacu kepada prinsip-prinsip syariah, agar setelah dikeluarkan tidak bertentangan dengan syariat itu sendiri, disamping hal ini merupakan suatu pola komersialisasi perbankan syariah.

3. Investasi Emas belum memiliki payung hukum dan pihak perbankan hendaknya tetap menjaga label kesyariahan agar orang-orang tidak menilai letak kekurangan dari perbankan syariah.

4. Hendaknya perbankan bisa menghilangkan transaksi yang bernuansa gharar, maysir dan kekurang sesuaian dengan standar operasional Procedure SOP, karena adanya SOP dalam suatu kebijakan tentu memiliki nilai manfaat bagi perbankan syariah sendiri.

5. Hendaknya perbankan syariah tidak mengejar suatu bisnis yang bernilai profit belaka, tetapi harus tetap memegang prinsip-prinsip dalam melakukan berbagai transaksi yang dilakukan.

Selain itu penting juga peran dari seluruh aspek masyarakat untuk melaporkan hal-hal yang kurang sesuai dengan prinsip syariah agar dapat menciptakan perbankan syariah yang siap jual dengan konsep ekonomi islam yang benar. 
Anggoro Sugeng: Analisis Prinsip Ekonomi Islam Terhadap Operasional Produk Investasi...

\section{DAFTAR PUSTAKA}

Al-Quran Karim dan Terjemahan Artinya. (1999). Yogyakarta: UII Press.

Anonim, "Perkembangan: Harga Emas", dikutip dari www.kitco.com, diakses 1 September 2011.

Chamid Nur. (2010). Jejak Langkah Sejarah Pemikiran Ekonomi Islam. Yogyakarta: Pustaka Pelajar.

Gufron Hamzah. (2011). "Faktor-faktor yang mempengaruhi Minat Nasabah dalam Produk Qardh dengan Gadai EMAS di PT. Bank Sumut Syariah Cabang Medan”, Skripsi, Universitas Sumatra Utara, Tidak Dipublikasikan.

"Investasi Emas". (2009). Majalah Sharing, Edisi 36, Tahun IV Desember, 2009.

"Investasi Gadai Emas Syariah". (2010). Majalah Sharing, Edisi 38, Tahun IV Februari 2010.

Haikal Tanti. (2011). Panduan Cerdas \& Syar'i Investasi Syariah Dinar-Emas-SukukRekesa Dana. Yogyakarta: Araska.

http://id.wikipedia.org diakses 14 Desember 2011.

Maya Irla Yulifa Eka. (2011). 'Prosedur Pembiayaan Islamic Banking (IB) Produk Gadai Emas Syariah pada PT. Bank BNI Syariah Kantor Cabang Surakarta", Skripsi, Universitas Sebelas Maret, Tidak Dipublikasikan.

Munrokhim Misanam, dkk. (2008). Ekonomi Islam. Jakarta: PT Raja Grafindo Persada.

Pusat Bahasa. (2008). Kamus Bahasa Indonesia, Edisi XVI. Jakarta: Pusat Bahasa.

Sumaji dkk,Kamus Ekonomi,(ttp: wipress, 2006).

"Standard Operating Procedure (SOP) Dana Talangan Gadai Emas di Perbankan Syariah", dikutip dari http://wmm.kontan.co.id diakses 3 Maret 2012.

TanInggrid, BIsnis dan Investasi Sistem Syariah, (Yogyakarta.: Universitas Atma Jaya Yogyakarta, 2009).

Sunarya. (2005). "Perencanaan Sistem Informasi Gadai Emas Syariah pada Bank Jabar Kantor Cabang Syariah Bandung”, Skripsi, Universitas Komputer Indonesia, Tidak Dipublikasikan. 